Original Research Paper

\title{
The Effect of Wall Type and Environmental Conditions toward Blood Type Identification Success Rate in Identifying Criminal Evident
}

\author{
Dinar Putri Rahayu ${ }^{1}$, Desti Christian Cahyaningrum ${ }^{1 *}$, Bowo Nurcahyo ${ }^{2}$ \\ ${ }^{1}$ Program Studi Biologi, Fakultas Biologi, Universitas Kristen Satya Wacana, Salatiga, Indonesia; \\ ${ }^{2}$ Laboratorium Forensik, Kepolisian Daerah Jawa Tengah, Semarang, Indonesia;
}

\author{
Article History \\ Received : July 01 ${ }^{\text {th }}, 2021$ \\ Revised : July $07^{\text {th }}, 2021$ \\ Accepted : July $20^{\text {th }}, 2021$ \\ Published : July $27^{\text {th }}, 2021$ \\ *Corresponding Author: \\ Desti Christian \\ Cahyaningrum, \\ Fakultas Biologi Universitas \\ Kristen Satya Wacana, \\ Salatiga, Indonesia; \\ Email: \\ desti.cahyaningrum@uksw.edu
}

\begin{abstract}
Findings of blood at the crime scene (TKP) can provide important information in criminal cases such as homicide. Blood findings at crime scenes are usually blood spots or traces of blood that can be found on various substrates. This study aims to determine the type of wall substrate and environmental conditions that have the ability to preserve blood better, prove by success rate in identifying blood type in ABO system until 336 hour of exposure. In this study, blood samples were exposed to three variations of wall substrates, namely plastered walls, plastered and painted walls, plastered and oil-painted walls; and in two different environmental conditions (indoor and outdoor). The method used to identify blood type in this study was absorption elution. First, blood samples from substrate was transferred to a gauze by $\mathrm{NaCl}$ $0,98 \%$. Then a confirmation test was carried out to ensure that the gauze sample contains a blood sample. Positive results of the confirmation test were indicated by a change in the color of the sample to bluish green when it is dripped with $\mathrm{H}_{2} \mathrm{O}_{2}$ and Leuco Malachite Green (LMG). The positive sample was then dripped with antiserum to determine the blood type. The success of identification of blood groups was indicated by the agglutination in the samples that were dripped with antisera A, because the blood samples used in this study are group A. The results showed that the success rate of blood group identification on the three types of substrates in the indoor environment for 336 hours was $100 \%$. Meanwhile, in the outdoor environment, only blood samples exposed to plastered wall substrate and wall paint for 264 hours could be identified for their blood type. It can be concluded that the three types of wall substrates have the same ability to preserve blood samples for up to 336 hours of exposure, but the environmental conditions that give the best percentage of successful blood group identification were in indoor conditions. For further research is recommended to focus on external environmental factors that have the most influence on the success of blood group identification in dried blood samples.
\end{abstract}

Keywords: Crime, ABO type of blood, Elution Absorption, forensics

\section{Pendahuluan}

Tindak kriminal merupakan segala bentuk tindakan yang merugikan secara ekonomis dan psikologis serta melanggar hukum, norma-norma sosial, dan agama. Tindak kriminal seperti pembunuhan, pemerkosaan, pembakaran, penembakan, perampokan dan lain sebagainya dapat meninggalkan bukti dari korban atau pelaku, salah satunya adalah bercak darah. Suryadi (2015) menyatakan bahwa bercak darah memiliki peranan penting untuk mengungkapkan berbagai kasus hukum maupun kasus kriminal. Hal ini sejalan dengan pernyataan Doty et al. (2016) yang menyebutkan bahwa temuan darah di Tempat Kejadian Perkara (TKP) mampu memberi informasi penting dalam kasus kriminal pembunuhan (Doty et al., 2016).

Pada proses identifikasi bercak darah sebagai barang bukti, hal yang harus dilakukan adalah memastikan terlebih dahulu apakah bercak darah tersebut memang benar 
mengandung molekul darah sehingga selanjutnya dapat diidentifikasi golongan darahnya. Identifikasi golongan darah umumnya dilakukan berdasarkan penggolongan darah sistem ABO. Sudah banyak kasus kriminal yang terungkap melalui identifikasi golongan darah sistem ABO, sehingga menjadi salah satu faktor utama dalam proses penyelidikan biologi forensik (Kumar et al., 2017).

Identifikasi golongan darah sistem $\mathrm{ABO}$ pada sampel darah yang masih segar lebih mudah dilakukan daripada sampel darah yang sudah kering. Hal ini dikarenakan sel-sel pada darah kering sudah rusak. Akan tetapi, identifikasi golongan darah sampel darah kering masih memungkinkan untuk dilakukan. Hal tersebut disebabkan karena antigen yang terdapat pada permukaan sel darah merah tetap utuh walaupun sel-sel telah hancur. Metode yang umum dilakukan untuk identifikasi golongan darah sampel darah kering adalah metode absorbsielusi. Metode ini merupakan metode yang sangat sensitif dan dapat mendeteksi adanya antigen secara tidak langsung $(\mathrm{Li}, 2015)$.

Keberhasilan identifikasi golongan darah dengan metode tersebut sangat dipengaruhi oleh kondisi sampel darah kering yang ditemukan di TKP. Sampel darah kering yang telah lama berada di TKP diduga lebih sulit untuk diidentifikasi dibanding sampel darah kering yang relatif lebih baru di TKP. Karena itu kecepatan penanganan penyidik menjadi faktor penting dalam proses identifikasi (Idries \& Tjiptmartono, 2011). Selain itu, jenis substrat tempat menempelnya bercak darah juga mempengaruhi kondisi sampel darah kering. Substrat tertentu diduga lebih dapat menyerap dan menyimpan sampel darah kering sehingga dapat bertahan lebih lama pada jenis substrat tersebut. Sementara substrat jenis lainnya diduga tidak dapat menyimpan sampel bercak darah karena porositasnya yang kurang memadahi sehingga sampel bercak darah lebih mudah tercuci ke lingkungan. Subsrat yang mungkin ditemukan di TKP salah satunya adalah substrat tembok. Substrat tersebut dapat ditemukan pada berbagai jenis perlakuan, seperti tembok yang dilepa, dilapisi cat tembok, maupun dilapisi cat minyak. Kemampuan substrat tembok dalam menyimpan sampel darah kering dipengaruhi oleh kondisi lingkungan tempat substrat tersebut berada. Pada lingkungan terbuka yang secara langsung dapat terkena hujan misalnya, maka sampel darah kering pada substrat tembok diduga akan lebih cepat tercuci dan tidak dapat diidentifikasi golongan darahnya.

Data mengenai tingkat keberhasilan identifikasi golongan darah pada berbagai jenis substrat dan kondisi selama kurun waktu tertentu menjadi penting sebagai acuan dalam mengidentifikasi barang bukti tindak kriminal. Ketersediaan data tersebut saat ini belum memadahi. Penelitian ini bertujuan untuk mengetahui pengaruh jenis substrat tembok serta kondisi lingkungan terhadap keberhasilan identifikasi sampel darah kering berdasarkan sistem penggolongan darah $\mathrm{ABO}$ hingga kurun waktu pemaparan 336 jam. Penelitian ini bermanfaat secara langsung untuk menyediakan data tingkat keberhasilan identifikasi golongan darah dalam upaya mengidentifikasi barang bukti tindak kriminal.

\section{Bahan dan Metode}

\section{Waktu dan Tempat penelitian}

Penelitian dilaksanakan di Fakultas Biologi Universitas Kristen Satya Wacana dan Laboratorium Forensik Cabang Semarang, Komplek Akademi Kepolisian (AKPOL), Semarang pada bulan Januari hingga Maret 2021.

\section{Bahan penelitian}

Pada penelitian ini, sampel darah dari probandus bergolongan darah $\mathrm{B}$ digunakan sebagai sampel darah yang dipaparkan ke beberapa jenis subtrat tembok; yaitu tembok dilepa, dilapisi cat tembok, dan dilapisi cat minyak. Pemaparan tersebut bertujuan sebagai simulasi untuk menguji tingkat keberhasilan identifikasi golongan darah pada ketiga jenis subtrat tembok dalam kondisi lingkungan terbuka dan tertutup hingga kurun waktu pemaparan 336 jam.

\section{Rancangan percobaan}

Penelitian ini merupakan penelitian eksperimental dengan Rancangan Acak Lengkap (RAL) faktorial. Terdapat dua faktor dalam penelitian ini, yaitu jenis substrat tembok dan kondisi lingkungan. Kedua faktor tersebut diuji melalui 6 jenis perlakuan dan 3 kali ulangan untuk tiap perlakuan, yang meliputi; darah pada substrat tembok yang dilepa di lingkungan 
terbuka (P1), darah pada substrat tembok yang dilapisi cat tembok di lingkungan terbuka (P2), darah pada substrat tembok yang dilapisi cat minyak di lingkungan terbuka (P3), darah pada substrat tembok yang dilepa di lingkungan tertutup (P4), darah pada substrat tembok yang dilapisi cat tembok di lingkungan tertutup (P5), serta darah pada substrat tembok yang dilapisi cat minyak di lingkungan tertutup (P6). Pemaparan darah pada substrat di semua perlakuan dilakukan selama kurun waktu hingga 336 jam dengan interval waktu pengamatan sebanyak 4 kali, yaitu pada kurun waktu 264 jam, 288 jam, 312 jam, dan 366 jam.

\section{Identifikasi Golongan Darah}

Menurut intruksi kerja Laboratorium Forensik Polri (2012), masing-masing sampel darah yang telah dipaparkan pada berbagai jenis substrat tembok selama kurun waktu tertentu dipindahkan ke kain kasa dengan cara mengusap kain kasa yang sudah diberi $\mathrm{NaCl} 0,98 \%$ pada substrat. Selanjutnya dilakukan uji konfirmasi dengan metode yang mengacu pada Medinger (1993) untuk memastikan bahwa kain kasa tersebut positif mengandung sampel darah. Sampel yang menunjukkan hasil positif pada uji konfirmasi kemudian diidentifikasi golongan darahnya dengan metode absorbsi elusi yang mengacu pada Kind (1960) dan Saluja (2014). Golongan darah ditentukan secara kualitatif dan ditunjukkan dengan adanya aglutinasi sampel yang ditandai dengan tidak lisisnya suspensi darah sebagai hasil positif.

\section{Analisis Data}

Data kualitatif berupa kenampakan sampel darah pada berbagai jenis substrat tembok selama kurun waktu tertentu, kenampakan hasil positif uji konfirmasi darah, serta hasil positif identifikasi golongan darah diamati dan dideskripsikan. Data kuantitatif berupa persentase keberhasilan identifikasi golongan darah pada semua perlakuan diuji secara statistik menggunakan uji Kruskal Wallis untuk mengetahui ada tidaknya beda nyata antar perlakuan serta uji korelasi Korelasi Kendall's untuk mengetahui korelasi antar faktor penelitian.

\section{Hasil dan Pembahasan}

\section{Uji Konfirmasi Darah}

Uji konfirmasi darah bertujuan untuk memastikan bahwa bercak darah yang dianalisis masih mengandung sampel darah kering sehingga dapat diidentifikasi lebih lanjut. Hasil positif uji konfirmasi ditunjukkan dengan adanyanya perubahan warna sampel menjadi hijau kebiruan ketika ditetesi dengan Hidrogen Peroksida $\left(\mathrm{H}_{2} \mathrm{O}_{2}\right)$ dan Leuco Malachite Green (LMG) (Gambar 1). Warna hijau kebiruan tersebut muncul akibat reaksi antara $\mathrm{H}_{2} \mathrm{O}_{2}$ dengan $\mathrm{Fe}$ yang terdapat pada hemoglobin dalam keadaan asam sehingga ion yang berikatan

(A)

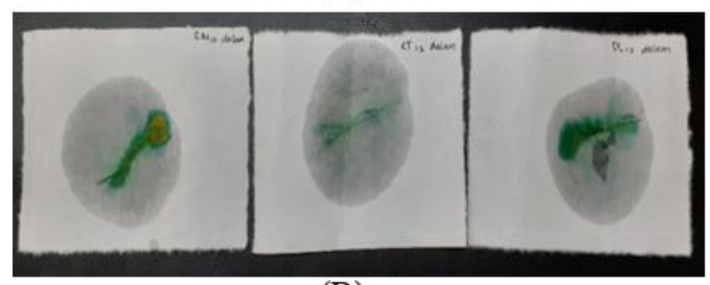

(B)

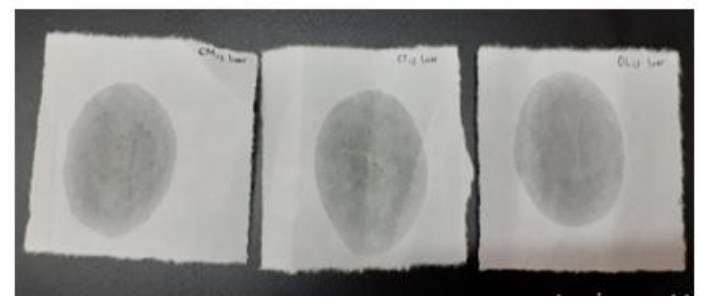

membentuk warna hijau kebiruan (Spalding, 2005)

Gambar 1. Hasil positif uji konfirmasi darah (A), Hasil negatif pada uji konfirmasi darah (B) (dok. pribadi, 2021).

Hasil dari uji konfirmasi darah menunjukkan bahwa pada semua perlakuan jenis substrat tembok di kondisi lingkungan tertutup masih mengandung sampel darah manusia hingga kurun waktu 336 jam. Pada kondisi lingkungan terbuka, hasil positif hanya ditemukan pada sampel darah yang dipaparkan pada tembok yang dilapisi cat tembok selama kurun waktu 264 jam. Perlakuan lainnya pada kondisi lingkungan terbuka menunjukkan hasil negatif (Tabel 1). Hal ini terjadi karena tidak ada $\mathrm{Fe}$ pada hemoglobin yang bereaksi dengan $\mathrm{H}_{2} \mathrm{O}_{2}$, sehingga dapat diketahui bahwa sampel hasil perlakuan tersebut tidak lagi mengandung sampel darah. 
Tabel 1. Hasil uji konfirmasi sampel darah (dok. pribadi, 2021)

\begin{tabular}{|c|c|c|c|c|c|}
\hline \multirow[b]{2}{*}{ Jenis subtrat tembok } & \multirow{2}{*}{$\begin{array}{c}\text { Kondisi } \\
\text { lingkungan }\end{array}$} & \multirow{2}{*}{$\begin{array}{c}\text { Waktu } \\
\text { pemaparan } \\
(\text { jam })\end{array}$} & \multicolumn{3}{|c|}{ Ulangan } \\
\hline & & & 1 & 2 & 3 \\
\hline \multirow{8}{*}{ Tembok dilepa } & \multirow{4}{*}{ Tertutup } & 264 & + & + & + \\
\hline & & 288 & + & + & + \\
\hline & & 312 & + & + & + \\
\hline & & 336 & + & + & + \\
\hline & \multirow{4}{*}{ Terbuka } & 264 & - & - & - \\
\hline & & 288 & - & - & - \\
\hline & & 312 & - & - & - \\
\hline & & 336 & - & - & - \\
\hline \multirow{8}{*}{ Tembok dilapisi cat tembok } & \multirow{4}{*}{ Tertutup } & 264 & + & + & + \\
\hline & & 288 & + & + & + \\
\hline & & 312 & + & + & + \\
\hline & & 336 & + & + & + \\
\hline & \multirow{4}{*}{ Terbuka } & 264 & + & + & + \\
\hline & & 288 & - & - & - \\
\hline & & 312 & - & - & - \\
\hline & & 336 & - & - & - \\
\hline \multirow{8}{*}{ Tembok dilapisi cat minyak } & \multirow{4}{*}{ Tertutup } & 264 & + & + & + \\
\hline & & 288 & + & + & + \\
\hline & & 312 & + & + & + \\
\hline & & 336 & + & + & + \\
\hline & \multirow{4}{*}{ Terbuka } & 264 & - & - & - \\
\hline & & 288 & - & - & - \\
\hline & & 312 & - & - & - \\
\hline & & 336 & - & - & - \\
\hline
\end{tabular}

Keterangan: (+) darah, (-) bukan darah

Hilangnya sampel darah pada perlakuan tersebut diduga terjadi akibat turunnya hujan deras selama waktu pemaparan yang menyebabkan sampel darah pada permukaan substrat terbawa aliran hujan. Oleh karena itu, teknik penyimpanan barang bukti telah terbukti menentukan kualitas sampel yang pada akhirnya menentukan keberhasilan dalam upaya penyelidikan kasus kriminal. Sampel darah yang dikeringkan secara alami pada suhu ruang dan setelah itu dibungkus dengan amplop kertas dapat bertahan hingga 3 tahun (Mohite, et al., 2011).

\section{Identifikasi Golongan Darah}

Kain kassa yang yang terkonfirmasi positif mengandung sampel darah kemudian diidentifikasi golongan darahnya dengan metode absorpsi elusi. Metode ini merupakan cara untuk menentukan golongan darah pertama kali digunakan oleh Siracus tahun 1930 yang diaplikasikan oleh semua laboratorium forensik karena terbukti lebih sensitif dan cocok (Ballal \& David, 2011). Pada metode tersebut, kain kassa yang sudah terkonfirmasi positif mengandung sampel darah dimasukkan dalam tabung reaksi untuk direaksikan dengan antisera. Antisera adalah reagen yang digunakan untuk pemeriksaan golongan darah ABO. Reagen ini diperoleh dari biakan supernatan secara in vitro yang berasal dari hibridisasi immunoglobin sel tikus (Oktari \& Silvia, 2016). Disediakan tiga jenis antisera berbeda untuk mengidentifikasi golongan darah pada sampel darah yang terdapat pada setiap kain kasa secara terpisah. Hasil positif ditunjukkan oleh terjadinya aglutinasi sebagai hasil reaksi darah dengan antisera tertentu, sedangkan hasil negatif ditunjukkan oleh tidak terjadinya aglutinasi serta terjadinya lisis yang ditunjukkan dengan keruhnya sampel ketika tabung dihomogenkan. Apabila aglutinasi terjadi pada tabung yang berisi kain kassa yang direaksikan dengan antisera $\mathrm{A}$, maka sampel darah pada kain kassa tersebut memiliki golongan darah A (Gambar 2). Intepretasi ini juga berlaku untuk hasil reaksi dengan antisera lainnya. Menurut Melati et al (2011), aglutinasi 
bisa terjadi karena adanya interaksi antibodi dengan antigen yang terikat pada eritrosit.

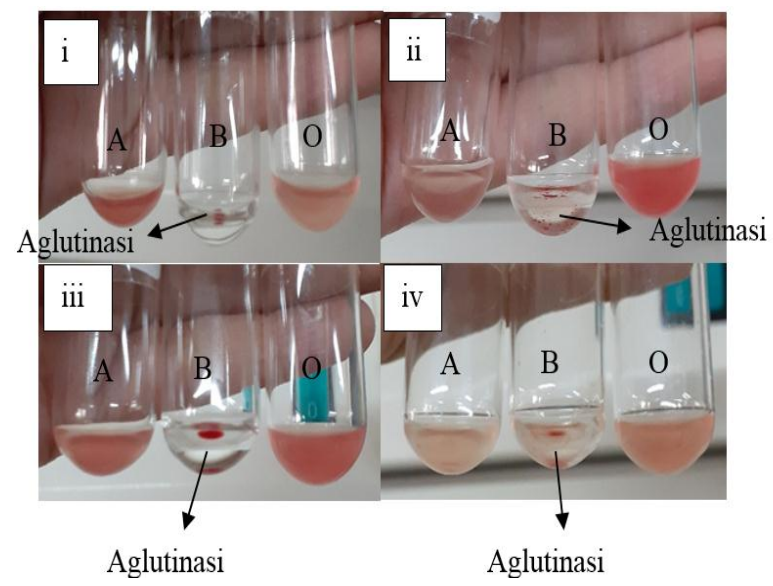

Gambar 2. Hasil identifikasi golongan darah dengan metode absorpsi elusi .Keterangan: (i) tembok dilepa tanpa dilapisi pada lingkungan tertutup 336 jam (ii) tembok dilepa dilapisi cat tembok dilapisi pada lingkungan tertutup 366 jam (iii) tembok dilepa dilapisi cat minyak dilapisi pada lingkungan tertutup 336 jam (iv) tembok dilepa dilapisi cat tembok dilapisi pada lingkungan terbuka 264 jam (dok pribadi, 2021)

Berdasarkan hasil identifikasi golongan darah, persentase keberhasilan identifikasi pada perlakuan lingkungan tertutup hingga kurun waktu 336 jam mencapai 100\% pada semua jenis substrat tembok (Tabel 2). Sedangkan pada kondisi lingkungan terbuka, hanya perlakuan pemaparan sampel darah pada substrat tembok dilapisi cat tembok dalam kurun waktu pemaparan 264 jam yang menunjukkan keberhasilan identifikasi. Perlakuan pemaparan sampel darah pada substrat tersebut di lingkungan terbuka dalam kurun waktu 288 jam, 312 jam, dan 336 jam menunjukkan persentase keberhasilan identifikasi sebesar 0\%. Selain itu, perlakuan pemaparan sampel darah ke jenis substrat lainnya di lingkungan terbuka, yaitu tembok dilepa dan tembok yang dilapisi cat minyak, juga tidak menunjukkan adanya keberhasilan identifikasi (persentase keberhasilan 0\%). Sehingga pada lingkungan terbuka, substrat tembok dilapisi cat tembok merupakan satu-satunya jenis substrat yang mampu mengawetkan sampel darah selama kurun waktu tidak lebih dari 264 jam.

Hasil tersebut menunjukkan bahwa keberhasilan identifikasi golongan darah pada kondisi lingkungan tertutup hingga kurun waktu pemaparan 336 jam tidak dipengaruhi oleh jenis substrat tembok. Sedangkan pada lingkungan terbuka, keberhasilan identifikasi golongan darah dapat dipengaruhi oleh jenis substrat tembok. Substrat tembok dilapisi cat tembok yang digunakan dalam percobaan, tidak mengandung lapisan cat dasar atau plamir. Menurut Avian (2017), cat dasar atau plamir berfungsi menutup pori-pori permukaan serta meningkatkan daya lekat cat terhadap substrat. Tidak tertutupnya pori-pori dengan sempurna karena tidak adanya plamir diduga menyebabkan sampel darah lebih dapat tertahan pada substrat tersebut dibandingkan substrat lainnya. Pada cat minyak misalnya, terdapat tambahan berupa lateks atau getah karet (Arisworo, 2006).

Tabel 2. Persentase keberhasilan identifikasi golongan darah pada setiap perlakuan (dok. pribadi, 2021)

\begin{tabular}{|c|c|c|c|}
\hline \multirow{2}{*}{ Substrat } & \multirow{2}{*}{$\begin{array}{c}\text { Lama } \\
\text { pemaparan } \\
\text { (jam) }\end{array}$} & \multicolumn{2}{|c|}{ Kondisi lingkungan } \\
\cline { 3 - 4 } & 264 & $100 \%$ & $0 \%$ \\
\hline Tembok & 288 & $100 \%$ & $0 \%$ \\
dilepa & 312 & $100 \%$ & $0 \%$ \\
tanpa & 336 & $100 \%$ & $0 \%$ \\
dilapisi & 336 & Terbuka \\
\hline Tembok & 264 & $100 \%$ & $100 \%$ \\
dilepa & 288 & $100 \%$ & $0 \%$ \\
dilapisi cat & 312 & $100 \%$ & $0 \%$ \\
tembok & 336 & $100 \%$ & $0 \%$ \\
\hline & & & \\
Tembok & 264 & $100 \%$ & $0 \%$ \\
dilepa & 288 & $100 \%$ & $0 \%$ \\
dilapisi cat & 312 & $100 \%$ & $0 \%$ \\
minyak & 336 & $100 \%$ & $0 \%$ \\
& & & \\
\hline
\end{tabular}

Melalui uji statistik terhadap persentase keberhasilan identifikasi pada semua perlakuan, diketahui bahwa data tidak berdistribusi normal (sig.< 0,05). Berdasarkan hasil uji normalitas tersebut, uji statistik dilakukan non parametrik dengan uji Kruskal wallis. Hasilnya menunjukkan bahwa rata-rata keberhasilan identifikasi golongan darah berbeda nyata secara signifikan hanya pada variabel kondisi lingkungan (Asymp. Sig.< 0,05). Hal tersebut menunjukkan bahwa secara statistik, jenis 
substrat tembok tidak berpengaruh secara signifikan terhadap keberhasilan identifikasi golongan darah pada sampel darah kering hingga kurun waktu pemaparan 336 jam. Akan tetapi, variabel kondisi lingkungan berpengaruh secara signifikan terhadap keberhasilan identifikasi hingga kurun waktu pemaparan 336 jam.

Kesimpulan tersebut diperkuat dengan hasil uji Korelasi Kendall's yang menunjukkan bahwa persentase keberhasilan berkorelasi sangat lemah terhadap jenis substrat dan waktu (dengan nilai korelasi berturut turut sebesar 0,00 dan -,102). Sebaliknya, hasil uji korelasi kedall's menunjukkan bahwa presentase keberhasilan berkorelasi kuat terhadap kondisi lingkungan (nilai korelasi sebesar -,920). Diketahui bahwa kondisi lingkungan berkorelasi negatif terhadap keberhasilan identifikasi golongan darah. Artinya, semakin sampel darah berada di lingkungan terbuka maka keberhasilan identifikasi golongan darah semakin rendah. Kondisi lingkungan tertutup mampu menghasilkan keberhasilan identifikasi golongan darah yang tinggi. Hal ini dikarenakan pada kondisi lingkungan tersebut, substrat lebih terlindungi dari hujan dan panas matahari sehingga dapat mengawetkan sampel darah kering dengan baik.

Pada penelitian ini, kondisi lingkungan terbuka yang dimaksud adalah sampel yang berada diluar ruangan yang langsung terpapar sinar matahari dan hujan secara langsung. Pada kondisi lingkungan tersebut, diketahui suhu selama pemaparan berlangsung mengalami perubahan antara pagi, siang, dan sore. Suhu tertinggi selama penelitian sebesar $28^{\circ} \mathrm{C}$. Suhu rata-rata dalam kondisi lingkungan tertutup sebesar $24,5^{\circ} \mathrm{C}$ dan dalam kondisi lingkungan terbuka sebesar $25,2^{\circ} \mathrm{C}$. Suhu selama penelitian tidak melebihi batas daya tahan antigen terhadap panas sehingga tidak mempengaruhi identifikasi golongan darah. Mernurut WHO faktor yang mempengaruhi proses identifikasi golongan darah salah satunya yaitu suhu, antibodi bereaksi optimal pada suhu $37^{\circ} \mathrm{C}$ (Mulyantari \& Yasa, 2016). Selain itu, persentase kelembaban pada lingkungan terbuka selama waktu pemaparan tidak mengalami perubahan yang jauh antara hari. Rata-rata kelembaban pada kondisi lingkungan tertutup sebesar $81,1 \%$ dan pada kondisi lingkungan terbuka sebesar $83,7 \%$.

Selama pemaparan, intensitas cahaya pada kondisi lingkungan terbuka juga diukur. Hasilnya menunjukkan bahwa IC pada penelitian ini mengalami perubahan antara hari. Rata-rata intensitas cahaya pada kondisi lingkungan tertutup sebesar 10.073 Lux dan pada kondisi lingkungan terbuka sebesar 95.111 Lux. Menurut Fujita, et al. (2005) cahaya dan temperatur dapat mempengaruhi bercak darah. Peningkatan temperatur dan interaksi dengan cahaya pada bercak darah dapat meningkatkan laju degredasi. Selain itu perubahan temperature, kelembaban, dan intensitas cahaya pada bercak darah mampu merubah warna pada bercak (Thanakiatkrai, 2013).

Selain itu, faktor lingkungan yang diduga paling berpengaruh terhadap keberhasilan identifikasi golongan darah di lingkungan terbuka adalah curah hujan. Selama waktu pemaparan, terjadi curah hujan dengan intensitas tinggi selama 6 jam pada kurun waktu pemaparan 0 jam. Dari data keseluruhan sampel darah mendapat paparan hujan sebanyak 9 kali selama 13 jam. Sehingga, ketidakberhasilan identifikasi pada kondisi lingkungan terbuka diduga kuat akibat sampel darah telah hilang dari permukaan substrat akibat hujan dengan intensitas tinggi yang turun sejak waktu pemaparan 0 jam. Hal ini menyebabkan sampel darah belum sempat masuk ke permukaan substrat dan terawetkan oleh substrat. Menurut Auliya (2017), air memiliki beberapa sifat, yaitu mengalir ke tempat yang lebih rendah, melarutkan beberapa zat, menempati ruang, dan memiliki berat. Oleh karena itu, perlu dilakukan penelitian lanjutan yang lebih fokus pada faktor lingkungan apa yang paling menentukan keberhasilan identifikasi golongan darah pada sampel darah kering terpapar di substrat tembok.

\section{Kesimpulan}

Berdasarkan hasil penelitian diketahui bahwa sampel darah kering yang dipaparkan pada ketiga jenis substrat di lingkungan tertutup menunjukkan persentase keberhasilan identifikasi golongan darah sistem ABO mencapai $100 \%$ hingga kurun waktu pemaparan 336 jam. Sehingga dapat disimpulkan bahwa kondisi lingkungan berpengaruh signifikan terhadap keberhasilan identifikasi golongan darah pada sampel darah kering yang dipaparkan di berbagai jenis substrat tembok. Sedangkan 
jenis substrat itu sendiri tidak berpengaruh secara signifikan terhadap keberhasilan identifikasi.

\section{Ucapan Terima Kasih}

Penulis mengucapkan terimaksih atas ijin serta dukungan dana penelitian berupa alat penelitian kepada Laboratorium Forensik Cabang Semarang, Komplek Akademi Kepolisian (AKPOL), Semarang. Ucapan terimakasih juga kepada Fakultas Biologi, Universitas Kristen Satya Wacana yang telah memfasilitasi kerjasama dengan Laboratorium Forensik.

\section{Referensi}

Andalusi, N. (2019). Identifikasi Golongan Darah pada Sampel Darah Kering yang Dipapar pada Substrat Tembok, Waktu, dan Lingkungan Berbeda. Skripsi. Purwokerto: Universitas Jendral Soedirman.

Dahlan, S. (2000). Ilmu kedokteran forensik pedoman bagi dokter dan penegak hukum. Semarang: Balai penerbit Universitas Diponegoro.

Arisworo, D. (2006). Ilmu Pengetahuan Alam Jakarta: Grafindo Media Utami.

Auliya, A.F.S. (2017). Pengembangan Media Pembelajaran "Watube" untuk Mengenalkan Sifat-Sifat Air pada Anak Tk Kelompok B. Jurnal Pendidikan Anak Usia Dini. 2(6), pp. 134-149.

Avian (2017). Plamir dan Cat Dasar. Online. [www.avianbrands.com], diakses tanggal 22 April 2021.

Ballal S, \& David MP. (2011). Determination of ABO Grouping from Dentine and Pulp. Pakistan Oral and Dental Journal, 31 (1).

Doty, K. C., McLaughlin, G., \& Lednev, I. K., (2016). A Raman "Spectroscopic Clock" for Bloodstain Age Determination: the First Week after Deposition. Anal Bioanal Chem, 408, pp. 3993-4001.
Fujita, Y., Tsuchiya, K., Abe, S., Takiguchi, Y., Kubi, S., \& Sakurai, H. (2005). Estimation of the age of human bloodstains by electron paramagnetic resonance spectroscopy: Longterm controlled experiment on the effects of environmental factors. Forensic Science International, 152, 39- 43

Hartika, R. I. (2020). Identifikasi Golongan Darah Sistem Abo Pada Sampel Darah Kering Yang Dipaparkan Pada Substrat Tembok Dengan Variasi Waktu Dan Kondisi Lingkungan Yang Berbeda. Skripsi. Yogyakarta: Universitas Ahmad Dahlan

Holzer, F.J. (1931). Ein einfaches verfahren zur gruppenbestimmung an vertrocknetem blut durch agglutininbindung. Deutsche Zeitschrift für die Gesamte Gerichtliche Medizin, 16, pp. 443-458.

Idries, A.M., \& Tjiptomartono, A.L. (2011). Penerapan Ilmu Kedokteran Forensik dalam Proses Penyidikan Edisi Revisi. Jakarta: CV. Agung Seto.

Isaac, L. J., Abah, G., Akpan, B., \& Ekaette, I. U. (2013). Haematological properties of different breeds and sexes of rabbits. Proceedings of the 18th Annual Conference of Animal Science Association of Nigeria, pp. 24-27

Kind, S. S. (1960). Absorption-elution Grouping of Dried Blood-Stains on Fabrics. Nature, 187(4739), pp. 789-790.

Kumagai, I., \& Tsumoto, K., (2001). AntigenAntibody Binding. Encyclopedia of Life Sciences. pp. 1-7.

Kumar, P. V., Vanoshree, M., Anila, K., Hunasgi, S., Suryadevra, S. S., \& Kardalkar, S. (2017). Determination of ABO Blood Grouping and Rhesus Factor from Tooth Material. Journal of Oral and maxillofacial Pathology, 20(3), pp. 540544. 
Li, R. (2015). Forensic Biology Second Edition. New York: Taylor \& Francis Group.

Medinger, P. (1933). Zum Nachweis Minimalster Blutspuren. Deutsche Zeitschrift für die Gesamte Gerichtliche Medizin. 16, Hal. 443-458.

Melati, E., Passarella, R., Primatha, R., \& Murdiansyah, A. (2011). Desain dan Pembuatan Alat Pendeteksi Golongan Darah Menggunakan Mikrokontroler. Jurnal Generic. 6(2).

Mulyantari, N.K. \& Yasa, P.S.I.W. (2016). Laboratorium Pratransfusi Up date. Denpasar: Udayana University Press.

Muhati, I. (2017). Keberhasilan Identifikasi Golongan Darah pada Sampel Darah Kering yang Terpapar Pada Substrat dan Kondisi Berbeda. Skripsi. Purwokerto: UNSOED.

Nadia, B. \& Handayani, D. \& Rismiati, R. (2010). Hidup Sehat Berdasarkan
Golongan Darah. Jakarta: Dukom Publisher.

Oktari, A., \& Silvia, N. D. (2016). Pemeriksaan Golongan Darah Sistem ABO Metode Slide dengan Reagen Serum Golongan Darah A, B, O. Jurnal Teknologi Laboratorium, 5(2), pp. 49-54.

Suryadi, T. (2015). Teknik Analisis DNA dalam Mengidentifikasi Genotip Golongan Darah pada Jenazah Kasus Forensik. Jurnal Kedokteran Syiah Kuala, 15(3), 157-161.

Spalding, R.P., (2005). Presumtive Testing and species Determination in Blood and Bloodstain in: James, S.H., Kish, P.E., Sutton, T.P., 2005. Principles of Bloodstain Pattern analysis Theory and Practice. Boca Racon: FL CRC press.

Thanakiatkrai, P., Yaodam, A. \& Kitpipit, T., (2013). Age estimation of bloodstains using smartphones and digital image analysis. Forensic science international, Volume 233, pp. 288-297. 